\title{
Peertechz
}

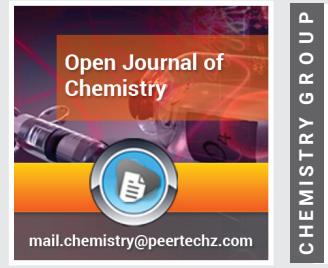

\section{Preparation of Aluminium}

\section{dodecaboride $\left(\mathrm{AlB}_{12}\right)$ powder \\ by Self-propagating High- temperature Synthesis (SHS)}

\section{Chao Wang ${ }^{1 *}$, Xiaoming $\mathrm{Cao}^{2}$, Mengge Dong ${ }^{3}$, Lu Zhang 4 , Jianxing $\mathrm{Liu}^{3}$, Xiaozhou $\mathrm{Cao}^{3}$ and Xiangxin $\mathrm{Xue}^{3 *}$}

${ }^{1}$ Department of Mechanical Engineering, the University of Texas at Dallas, Richardson, TX, 75080, USA

${ }^{2}$ Institute of Metal Research, Chinese Academy of Science, Shenyang, Liaoning, 110016, China

${ }^{3}$ School of Metallurgy, Northeastern University, Shenyang, Liaoning, 110819, China

${ }^{4}$ School of Energy and Environment, Anhui University of Technology, Ma'anshan, 243002, China
Received: 11 February, 2021

Accepted: 17 February, 2021

Published: 18 February, 2021

*Corresponding authors: Chao Wang, Department of Mechanical Engineering, the University of Texas at Dallas, Richardson, TX, 75080, USA, Tel: 1-469-660-9625; E-mail:wang.chao@utdallas.edu

Xiangxin Xue, School of Metallurgy, Northeastern University, Shenyang, Liaoning, 110819, China,

E-mail:xuexx@mail.neu.edu.cn

ORCID: https://orcid.org/0000-0002-6668-704X

Keywords: AlB $_{12}$; SHS; Microstructure; Adiabatic temperature; Component

https://www.peertechz.com

Check for updates

\begin{abstract}
Self-propagating High-temperature Synthesis (SHS) process is used to prepare Aluminium dodecaboride $\left(\mathrm{AlB}_{12}\right)$. The phase analysis results of preparing $\mathrm{AlB}_{12}$ with $\mathrm{Al}$ and $\mathrm{B}_{2} \mathrm{O}_{3}$ as raw materials show that under air and argon conditions, the self-propagating and acid-washed self-propagating powders all have $\mathrm{a}-\mathrm{Al}_{2} \mathrm{O}_{3}$ impurities when $\mathrm{Mg}, \mathrm{Al}$ and $\mathrm{B}_{2} \mathrm{O}_{3}$ are used as raw materials. The phase analysis results of the preparation of $\mathrm{AlB}_{12}$ show that under argon conditions, the self-propagating and acid-washed, self-propagating powder has un-removable $\mathrm{MgAl}_{2} \mathrm{O}_{4}$ impurities, and the root cause of the low purity of $\mathrm{AlB}_{12}$ prepared by the self-propagating method is the presence of un-removable impurities.
\end{abstract}

\section{Introduction}

Most of the borides are crystals with high hardness and melting point [1-4]. Stable chemical properties and a wide range of applications make it widely used in composite materials, semiconductors, and in various areas of national defense, such as radiation protection [5-8]. Among them, $\mathrm{AlB}_{12}$ has a special electronic structure and bonding characteristics $[9,10]$. It can effectively adjust the conductivity of semiconductor materials, and thus is extensively employed in conductors and semiconductor materials. In addition to the above characteristics, the content of boron in $\mathrm{AlB}_{12}$ is extremely high, reaching $82.8 \%$, which is very promising as neutron shielding material [11-13].

Ceramic powders are usually synthesized by traditional sintering methods [14-16]. However, the use of this method to synthesize ceramic powder takes a long time, consumes a great deal of energy and pollution [17]. Self-propagating hightemperature synthesis (SHS) is a unique technique for synthesizing materials by self-heating and self-conduction of high chemical reaction heat between reactants. This technology was first discovered by Merzhanov et al., in their research on the combustion of solid propellants in rockets and was announced in 1967. Compared with the conventional sintering method, the advantages of the SHS method can be summarized as follows: (1) It is time saving and makes full use of energy [18]. (2) It requires only simple equipment and processes [19]. (3) The high product purity and product conversion rate are close to $100 \%$ [20]. (4) It can not only produce ceramic powder, but if the proper amount of pressure is applied at the same time, high-density combustion products can also be produced [21]. (5) High output [22].

In previous studies, $\mathrm{AlB}_{12}$ powder was fabricated by using the SHS method [23-25]. The calculation results of preparing 
$\mathrm{AlB}_{12}$ with $\mathrm{Mg}, \mathrm{Al}_{2} \mathrm{O}_{3}$ and $\mathrm{B}_{2} \mathrm{O}_{3}$ as raw materials show that the adiabatic temperature of the system is $2789.5 \mathrm{~K}$, which satisfies the self-propagating reaction conditions. Further, the phase analysis results show that there is no matter in air or argon, the self-propagating powder and the acid-washed selfpropagating powder all have $\mathrm{Mg}_{0.4} \mathrm{Al}_{2.4} \mathrm{O}_{4}$ impurities, and the purity of the prepared $\mathrm{AlB}_{12}$ is not high.

Although $\mathrm{AlB}_{12}$ is produced, $\mathrm{Mg}_{0.4} \mathrm{Al}_{2.4} \mathrm{O}_{4}$ has not been removed and still exists. In this work, $\mathrm{Al}, \mathrm{B}_{2} \mathrm{O}_{3}$ and $\mathrm{Mg}, \mathrm{Al}, \mathrm{B}_{2} \mathrm{O}_{3}$ were used as raw materials to conduct experimental studies on self-propagating synthesis of $\mathrm{AlB}_{12}$.

\section{Experimental procedure}

The starting materials used in this research were $\mathrm{Al}$ powder (purity $>99 \% \mathrm{Al}$, average particle size $50 \mu \mathrm{m}$, provided by Dandong Chemical Research Institute, Dandong, China), B2O3 powder (purity $>99 \%$, average particle size $96 \mu \mathrm{m}$, provided by Dandong Chemical Research Institute, Dandong, China), and $\mathrm{Mg}$ powder (purity $>98 \%$, average particle size $100 \mu \mathrm{m}$, provided by Dandong Chemical Research Institute, Dandong, China).

The steps used in the self-propagating process to synthesize $\mathrm{AlB}_{12}$ ceramic powder are as follows: (1) Weigh a certain amount (in proportion to the reaction equation) of the original material powder, place it in the ball milling tank, and mix the ball mill for 2 hours. (2) Intercept the resistance wire and connect it to the two poles of the self-propagating device and place the material in the atmosphere with one end close to the resistance wire. (3) Start the ignition device and slowly increase the current. When the pointer fluctuates sharply, reduce the current and keep the current increasing steadily. Finally, the resistance wire will reach a molten state when the material is induced to burn, and the current is turned off. (4) The reaction product is pulverized and sieved with 160 meshes, and samples under the sieve are sampled for detection and analysis.

The phase analysis of the synthesized powder was carried out using an X-ray diffractometer (XRD, X'Pert Pro MRD, Netherlands) with a Philips diffractometer using $\mathrm{Cu}$ Ka. The microstructure of powders and elements analysis were investigated using a scanning electron microscope with EDS detector (SEM, S-3400N, Japan).

This article focuses on the study of two reaction systems, system 1: $\mathrm{Al}$ and $\mathrm{B}_{2} \mathrm{O}_{3}$, and system 2: $\mathrm{Mg}, \mathrm{Al}$, and $\mathrm{B}_{2} \mathrm{O}_{3}$. Two experimental atmospheres are used in both systems (Table 1 ).

In the $\mathrm{Al}-\mathrm{B}_{2} \mathrm{O}_{3}$ system, the following chemical reactions mainly occur:

$$
13 \mathrm{Al}+6 \mathrm{~B}_{2} \mathrm{O}_{3} \rightarrow \mathrm{AlB}_{12}+6 \mathrm{Al}_{2} \mathrm{O}_{3}
$$

In the $\mathrm{Mg}-\mathrm{Al}-\mathrm{B}_{2} \mathrm{O}_{3}$ system, the following chemical reactions mainly occur:

$$
\begin{aligned}
& 3 \mathrm{Mg}+\mathrm{B}_{2} \mathrm{O}_{3} \rightarrow 2 \mathrm{~B}+3 \mathrm{MgO} \\
& \mathrm{Al}+12 \mathrm{~B} \rightarrow \mathrm{AlB}_{12}
\end{aligned}
$$

$$
18 \mathrm{Mg}+\mathrm{Al}+6 \mathrm{~B}_{2} \mathrm{O}_{3} \rightarrow \mathrm{AlB}_{12}+18 \mathrm{MgO}
$$

After the combustion synthesis, the extraneous components were leached out from the synthesized powder with $60^{\circ} \mathrm{C}$ in diluted $\mathrm{HCl}$ ( $\mathrm{pH}$ value is 3 ).

\section{Results and discussion}

Figure 1 is the X-ray diffraction pattern of $\mathrm{Al}$ and $\mathrm{B}_{2} \mathrm{O}_{3}$ prepared under both air conditions (before and after pickling) and argon conditions (before and after pickling) respectively. It can be seen from the figure that in either air or argon conditions, irremovable $\mathrm{Al}_{2} \mathrm{O}$ is found in the bottom. Analysis of its crystal

\begin{tabular}{|c|c|c|c|}
\hline \multicolumn{1}{|c|}{ Table 1: The experimental scheme of tests. } \\
\hline $\begin{array}{c}\text { Serial } \\
\text { condition }\end{array}$ & Reactant & Atmosphere & Pickling \\
\hline S1 & $\mathrm{Al}+\mathrm{B}_{2} \mathrm{O}_{3}$ & Air & Before pickling \\
\hline S2 & $\mathrm{Al}+\mathrm{B}_{2} \mathrm{O}_{3}$ & Air & After pickling \\
\hline S3 & $\mathrm{Al}+\mathrm{B}_{2} \mathrm{O}_{3}$ & $\mathrm{Ar}$ & Before pickling \\
\hline S4 & $\mathrm{Al}+\mathrm{B}_{2} \mathrm{O}_{3}$ & $\mathrm{Ar}$ & After pickling \\
\hline S5 & $\mathrm{Mg}+\mathrm{Al}^{+}+\mathrm{B}_{2} \mathrm{O}_{3}$ & $\mathrm{Ar}$ & Before pickling \\
\hline S6 & $\mathrm{Mg}+\mathrm{Al}+\mathrm{B}_{2} \mathrm{O}_{3}$ & $\mathrm{Ar}$ & After pickling \\
\hline
\end{tabular}

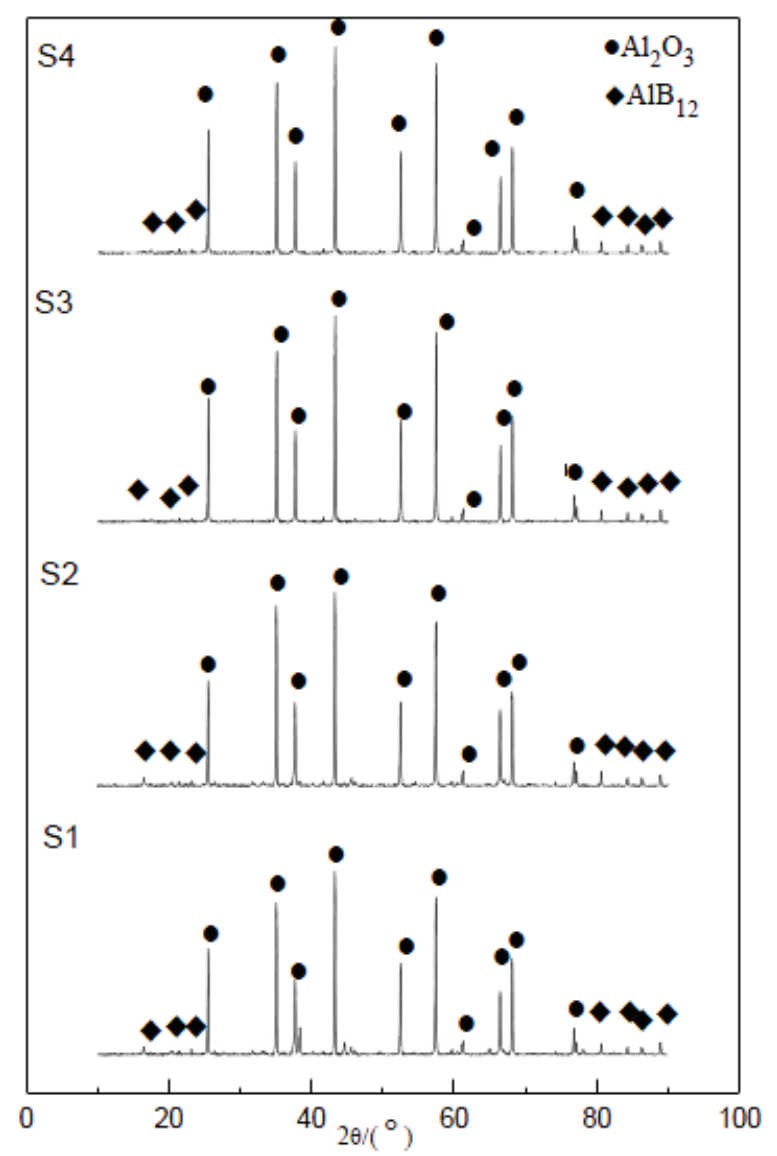

Figure 1: XRD patterns of fabrication $\mathrm{AlB}_{12}$ from $\mathrm{Al}$ and $\mathrm{B}_{2} \mathrm{O}_{3}$ 
structure revealed that the $\alpha-\mathrm{Al}_{2} \mathrm{O}_{3}$ is corundum, an extremely stable substance that is difficult to remove through physical and chemical reactions. Therefore, $\mathrm{AlB}_{12}$ prepared from $\mathrm{Al}$ and $\mathrm{B}_{2} \mathrm{O}_{3}$, contains a large amount of inseparable corundum, which contributes to the failure of the self-propagating preparation of $\mathrm{AlB}_{12}$ using $\mathrm{Al}$ and $\mathrm{B}_{2} \mathrm{O}_{3}$ as raw materials.

Figure 2 is the $\mathrm{X}$-ray diffraction pattern of powder prepared with $\mathrm{Mg}, \mathrm{Al}$ and $\mathrm{B}_{2} \mathrm{O}_{3}$ under argon conditions (before pickling). From the results of phase analysis, the main components of the coarse powder before pickling are $\mathrm{MgO}, \mathrm{Mg}_{3} \mathrm{~B}_{2} \mathrm{O}_{6}, \mathrm{MgAl}_{2} \mathrm{O}_{4}$, and $\mathrm{AlB}_{12}$, while in the powder after pickling, when $\mathrm{MgO}$ and $\mathrm{Mg}_{3} \mathrm{~B}_{2} \mathrm{O}_{6}$ are removed, the main impurity is $\mathrm{MgAl}_{2} \mathrm{O}_{4}$. This shows that the purity of $\mathrm{AlB}_{12}$ is not high when prepared by self-propagating, self-propagation when the raw materials used are $\mathrm{Mg}, \mathrm{Al}$ and $\mathrm{B}_{2} \mathrm{O}_{3}$.

Figure 3 shows the microscopic morphology of powder prepared through use of the self-propagating method under argon conditions with $\mathrm{Al}$ and $\mathrm{B}_{2} \mathrm{O}_{3}$ as raw materials after pickling. From an analysis of the energy spectrum results, the A particles - with obvious layering phenomenon on the left are $\mathrm{Al}_{2} \mathrm{O}_{3}$ particles - while the $\mathrm{B}$ particles - with more obvious granular shape on the right - are $\mathrm{AlB}_{12}$. This situation shows that despite the pickling treatment, $\mathrm{Al}_{2} \mathrm{O}_{3}$ is still untreated. It also shows that the unremovable by-product $\mathrm{Al}_{2} \mathrm{O}_{3}$ uses $\mathrm{Al}$ and $\mathrm{B}_{2} \mathrm{O}_{3}$ as raw materials and is the biggest obstacle to selfpropagating preparation of $\mathrm{AlB}_{12}$.

Table 2 shows the elemental analysis results of EDS analysis after pickling of $\mathrm{Al}$ and $\mathrm{B}_{2} \mathrm{O}_{3}$ as raw materials and selfpropagating preparation of $\mathrm{AlB}_{12}$ with $\mathrm{Mg}, \mathrm{Al}$, and $\mathrm{B}_{2} \mathrm{O}_{3}$ as raw materials. From the results in the table, the acid wash product prepared with the use of $\mathrm{Al}$ and $\mathrm{B}_{2} \mathrm{O}_{3}$ as raw materials has the highest content of $\mathrm{O}$ element, followed by $\mathrm{B}$ and $\mathrm{Al}$. Observing the test samples, there are still insoluble substances, so the test results are also relatively incomplete. This shows that under argon conditions, using $\mathrm{Al}$ and $\mathrm{B}_{2} \mathrm{O}_{3}$ as raw materials to prepare $\mathrm{AlB}_{12}$ and using the self-propagating method, the purity of $\mathrm{AlB}_{12}$ in the prepared product is low, and the $\mathrm{B}$ content is insufficient.

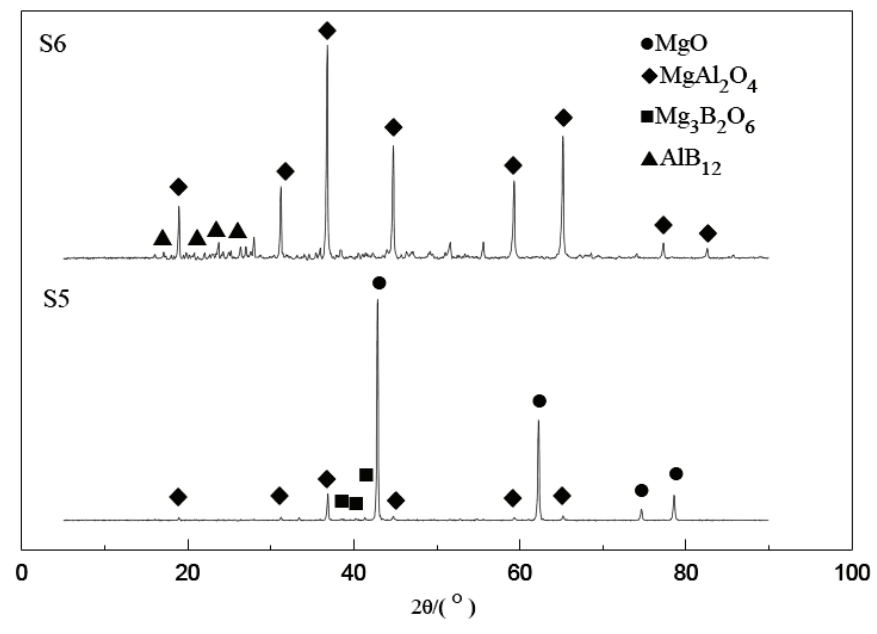

Figure 2: XRD patterns of fabrication $\mathrm{AlB}_{12}$ from $\mathrm{Mg}, \mathrm{B}_{2} \mathrm{O}_{3}$ and $\mathrm{Al}_{2} \mathrm{O}_{3}$.

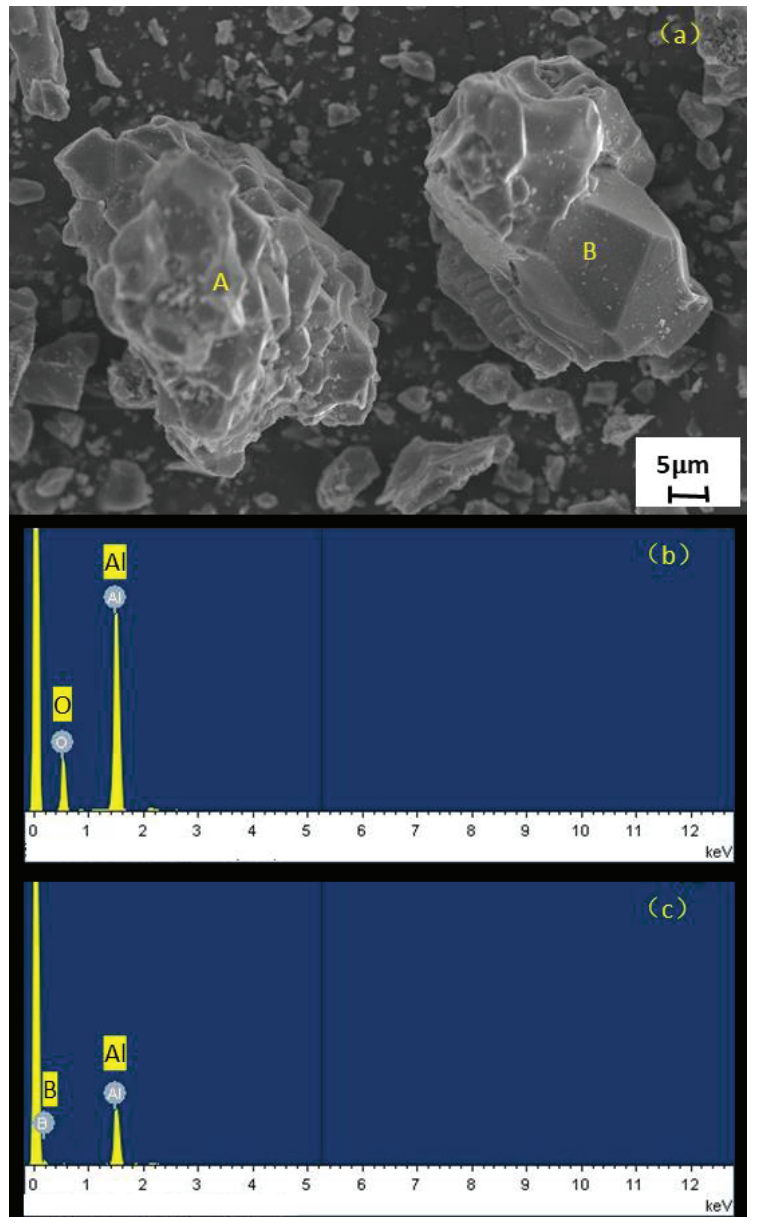

Figure 3: (a): Microstructure photographs of powder by SHS; (b): EDS analysis of A area; (c): EDS analysis of B area.

Table 2: The results of elementary analysis (mass fraction, \%)

\begin{tabular}{|c|c|c|c|c|}
\hline Serial & B & Mg & Al & 0 \\
\hline S4 & 12.6 & - & 2.21 & 85.19 \\
\hline S6 & 58.5 & 9.62 & 3.43 & 28.45 \\
\hline
\end{tabular}

\section{Summary}

The phase analysis results of preparing $\mathrm{AlB}_{12}$ using $\mathrm{Al}$ and $\mathrm{B}_{2} \mathrm{O}_{3}$ as raw materials shows that there are $\alpha-\mathrm{Al}_{2} \mathrm{O}_{3}$ impurities in the self-propagating powder regardless of either the air condition or the argon condition, and it cannot be removed. Consequently, the purity of the prepared $\mathrm{AlB}_{12}$ is not high. The phase analysis results of preparing $\mathrm{AlB}_{12}$ using $\mathrm{Mg}, \mathrm{Al}$ and $\mathrm{B}_{2} \mathrm{O}_{3}$ as raw materials indicates that the self-propagating and acid-washed self-propagating powder has unremovable $\mathrm{MgAl}_{2} \mathrm{O}_{4}$ impurities under argon conditions, and the purity of the prepared $\mathrm{AlB}_{12}$ is not high, causing self-propagation. The fundamental reason for the low purity of $\mathrm{AlB}_{12}$ prepared by this method is the existence of impurities that cannot be removed. For future research work, it may be very promising to consume $\mathrm{Al}_{2} \mathrm{O}_{3}$ through aluminum electrolysis.

\section{Notes}

The authors declare that they have no competing financial interest. 


\section{Acknowledgements}

This work was supported by the fundamental, scientificresearch business resources of the central universities (award \# N10060200).

\section{References}

1. Wang C, Xue X, Cao X, Yang H (2012) Effect of BN Addition on Mechanical Properties and Microstructure of $\mathrm{TiB}_{2}$-Al Composites, Journal of Northeastern University (Natural Science) 19. Link: https://bit.ly/37nZLbx

2. Cao X, Wang C, Shi L, Yang H, Xue X, et al. (2013) Effect of Ni addition on pressureless sintering of tungsten diboride. International Journal of Refractory Metals and Hard Materials 41: 597-602. Link: https://bit.ly/2NzrKhg

3. Cao X, Wang C, Xue X, Yang H (2014) Preparation of tungsten boride ceramic by pressureless sintering. Journal of Inorganic Materials 29: 498-502. Link: https://bit.ly/3jUoYzk

4. Matkovich VI (1977) Boron and refractory borides, Springer. Link: https://bit.ly/37oSA30

5. Cao X, Wang C, Xue X, Cheng G (2015) Effect of ti addition on the residual aluminium content and mechanical properties of the $\mathrm{B}_{4} \mathrm{C}$-al composites produced by vacuum infiltration. Archives of Metallurgy and Materials 60 : 2493-2398. Link: https://bit.ly/3s4vdTY

6. Dong $M$, Xue X, Yang H, Liu D, Wang $C$, et al. (2016) A novel comprehensive utilization of vanadium slag: as gamma ray shielding material. Journal of Hazardous Materials 318: 751-757. Link: https://bit.ly/3qsmAm7

7. Qi D, Yong G, Zhiheng R, Xiaoming C, Chao W, et al. (2019) Preparation and Erosion Performance for Co-continuous Phase Composites of $\mathrm{Si}_{3} \mathrm{~N}_{4} / 1 \mathrm{Cr} 18 \mathrm{Ni9Ti}$, Chinese Journal of Materials Research 33: 34-42. Link: https://bit.ly/3dkcH61

8. Cao X, Wang $H$, Meng $X$, Wang $C$, Yang $H$, et al. (2011) High temperature electrochemical synthesis of tungsten boride from molten salt. Advanced Materials Research. 463-466. Link: https://bit.ly/3qt80L2

9. Gosset D, Guery M, Kryger B (1991) Thermal properties of some boron-rich compounds ( $(\mathrm{BnC})$ and $\left.\mathrm{AlB}_{12}\right)$. AIP Conference Proceedings American Institute of Physics 231: 380-383. Link: https://bit.ly/3pnQuX3

10. Wang C, Cao X, Jiang T, Rong Y, Zhang J, et al. (2013) Research Progress on Aluminum-Boron Compounds (Al-B) and Its Composite Materials. Bulletin of the Chinese Ceramic Society 26. Link: https://bit.ly/3aq3eYV

11. Higashi I (2000) Crystal chemistry of a-AlB ${ }_{12}$ and $y-A_{1} B_{12}$. Journal of solid state chemistry 154: 168-176. Link: https://bit.ly/3s3wMls

12. Mahesh V, Nair PS, Rajan T, Pai B, Hubli R (2011) Processing of surface treated boron carbide-reinforced aluminum matrix composites by liquidmetal stir-casting technique. Journal of Composite Materials 45: 2371-2378. Link: https://bit.ly/3psSD43

13. Mahmoudi M, Wang C, Moreno S, Burlison SR, Alatalo D, et al. (2020) ThreeDimensional Printing of Ceramics through "Carving" a Gel and "Filling in" the Precursor Polymer. ACS Appl Mater Interfaces 12: 31984-31991. Link: https://bit.ly/3ptAS4k

14. Luo X, Wang Z, Hu X, Shi Z, Gao B, et al. (2009) Influence of metallic additives on densification behaviour of hot-pressed $\mathrm{TiB}_{2}$. Light Metals 1151-1155. Link: https://bit.ly/3bhouzk

15. Wang C, Hossain Bhuiyan ME, Moreno S, Minary-Jolandan M (2020) Direct-
Write Printing Copper-Nickel (Cu/Ni) Alloy with Controlled Composition from a Single Electrolyte Using Co-Electrodeposition. ACS Applied Materials \& Interfaces 12: 18683-18691. Link: https://bit.ly/3asMa4J

16. Chao W, Xiangxin X, Xiaozhou C, Lu Z, Jian Z, et al. (2013) A New Method of Fabricating AIN-TiB2 Composite Ceramics. Materials and Manufacturing Processes 28: 953-956. Link: https://bit.ly/37nfwiV

17. Chao W, Xiangxin X, Xiaozhou C, He Y, Gongjin C (2013) The effect of Ti addition on the microstructure and fracture toughness of BN-Al composite materials synthesized by vacuum infiltration. Archives of Metallurgy and Materials 58: 509-512. Link: https://bit.ly/3qzcfVy

18. Cao X, Xu L, Wang C, Li S, Wu D, et al. (2020) Electrochemical Behavior and Electrodeposition of Sn Coating from Choline Chloride-Urea Deep Eutectic Solvents. Coatings 10: 1154. Link: https://bit.ly/3dlvD4A

19. Tao W, Wang Z, Chen G, Shi Z, Gao B, et al. (2009) Finite element analysis of thermo-electric coupled field in 400kA large-scale aluminum reduction cell. 2009 World Non-Grid-Connected Wind Power and Energy Conference. IEEE 1-4. Link: https://bit.ly/3jTrUfM

20. Subrahmanyam J, Vijayakumar M (1992) Self-propagating hightemperature synthesis. Journal of Materials Science 27: 6249-6273. Link: https://bit.ly/3dm5bYf

21. Merzhanov A (1995) History and recent developments in SHS. Ceramics International 21: 371-379. Link: https://bit.ly/3ppyY4N

22. Yukhvid V (1992) Modifications of SHS processes. Pure Appl Chem 64: 977 988. Link: https://bit.ly/3qoHwKy

23. Wang C, Ma B, Zhang L, Cao X, Yang H, et al. (2014) Elementary research on preparation of $\mathrm{AlB}_{12}$ powder by self-propagating high-temperature synthesis (SHS), Materials Science Forum. Trans Tech Publ 365-369. Link: https://bit.ly/3prLjWf

24. Odawara O (2010) Mass-forced SHS technology of ceramic materials. Trans Tech Publ 302-311. Link: https://bit.ly/3qoHouy

25. Huang KJ, Yan L, Kou HM, Xie CS (2010) Synthesis of Al203/AlB12/A composite ceramic powders by a new laser-induction complex heating method and a study of their mechanical properties. Applied Mechanics and Materials 596-601. Link: https://bit.ly/2Zmne8u

Discover a bigger Impact and Visibility of your article publication with

Peertechz Publications

Highlights

* Signatory publisher of ORCID

* Signatory Publisher of DORA (San Francisco Declaration on Research Assessment)

* Articles archived in worlds' renowned service providers such as Portico, CNKI, AGRIS, TDNet, Base (Bielefeld University Library), CrossRef, Scilit, J-Gate etc

* Journals indexed in ICMJE, SHERPA/ROMEO, Google Scholar etc.

* OAl-PMH (Open Archives Initiative Protocol for Metadata Harvesting)

* Dedicated Editorial Board for every journal

* Accurate and rapid peer-review process

* Increased citations of published articles through promotions

* Reduced timeline for article publication

Submit your articles and experience a new surge in publication services (https://www.peertechz.com/submission).

Copyright: @ 2021 Wang C, et al. This is an open-access article distributed under the terms of the Creative Commons Attribution License, which permits unrestricted use, distribution, and reproduction in any medium, provided the original author and source are credited.

Citation: Wang C, Cao X, Dong M, Zhang L, Liu J, et al. (2021) Preparation of Aluminium dodecaboride (AlB ${ }_{12}$ ) powder by Self-propagating High-temperature Synthesis (SHS). Open Journal of Chemistry 7(1): 025-028. DOI: https://dx.doi.org/10.17352/ojc.000025 